\title{
ESTUDANDO A METÁFORA VERBAL A PARTIR DA TEORIA DA INTERAÇÃO
} SEMÂNTICA ${ }^{1}$

STUDYING THE VERBAL METAPHOR ACCORDING TO THE SEMANTIC INTERACTION THEORY

Thabyson Sousa Dias

Dieysa Kanyela Fossile

Universidade Federal do Tocantins- UFT

\section{RESUMO}

Por meio deste estudo, desenvolvemos uma análise descritiva e comparativa de sentenças metafóricas que apresentam verbos com significados aspectuais iterativos e cursivos. $\mathrm{O}$ corpus analisado nesta pesquisa, de cunho quali-quantitativa, possui um total de 129 metáforas do Português Brasileiro e do Inglês. A análise e a descrição dos dados foram realizadas a partir da Teoria da Interação Semântica de Black (1993), pois a mesma entende e enfatiza que a metáfora é um fenômeno especial em que os termos que compõem o enunciado interagem, gerando uma operação mental, na perspectiva de que a linguagem cria realidades e formas de pensar (Fossile, 2008a, 2008b, 2008c, 2011a, 2011b, 2012b, 2012c; Dias e Fossile, 2014). A metodologia utilizada para a análise descritiva e comparativa das ocorrências metafóricas do Português Brasileiro e do Inglês foi elaborada por Moura (2007) e Fossile (2008a; 2008b; 2008c, 2011a, 2012b, 2012c). Concluímos que há regularidade ao interpretar metáforas do Português Brasileiro e do Inglês e que ao interpretarmos uma metáfora não realizamos a interpretação de maneira casual e aleatória, mas parece-nos que recorremos a uma estrutura concebida cognitivamente, na qual os valores aspectuais juntamente com a interação entre o tópico e o veículo da sentença metafórica parecem ser o ponto mais importante.

Palavras-chave: Metáfora, Aspecto verbal, Teoria da Interação Semântica.

\section{ABSTRACT}

Through this study, we develop a descriptive and comparative analysis of metaphorical sentences which contain verbs with iterative and cursive aspectual meanings. The corpus analyzed in this qualitative and quantitative research has a total of 129 metaphors of Brazilian Portuguese and English. The analysis and description of the data were performed from the Semantic Interaction Theory by Max Black (1993), because it understands and emphasizes that metaphor is a special phenomenon in which the terms that make up the statement interact creating a mental operation, in a view that the language creates reality and ways of thinking (Fossile, 2008a, 2008b, 2008c, 2011a, 2011b, 2012b, 2012c; Dias and Fossile 2014). The methodology used for this descriptive and comparative analysis of the metaphorical occurrences of Brazilian Portuguese and English was developed by Moura (2007) and Fossile (2008a; 2008b; 2008c, 2011a, 2012b, 2012c). We can conclude that there is regularity in interpreting metaphors of Brazilian Portuguese and English and when we interpret a metaphor we do not perform a casual or random interpretation, but it seems to us that we recourse to a structure designed cognitively, in which aspectual values along with the interaction between the topic and the vehicle of a metaphorical sentence seem to be the most important point.

\footnotetext{
${ }^{1}$ Trabalho premiado no $10^{\circ}$ Seminário de Iniciação Científica da Universidade Federal do Tocantins, realizado de 24 a 28 de novembro de 2014, em Palmas-TO.
} 
Keywords: Metaphor, Verbal aspect, Semantic Interaction Theory.

Recebido em 07/09/2015. Aceito em 24/09/2015. Publicado em 03/12/2015.

O estudo da metáfora é uma caminhada repleta de surpresas, pois nos faz perceber que o que sabemos é muito pouco, e que o que compreendemos é apenas uma pequena parte do que a metáfora realmente pode vir a ser. Assim como outros estudos que se ocupam em compreender a metáfora em sua essência, nós também pretendemos fazer o mesmo, pois este estudo visa de um modo geral, desenvolver uma análise descritiva e comparativa de sentenças metafóricas que apresentam verbos com significados aspectuais iterativos e cursivos. A partir do estudo "Buscando regularidades interpretativas nas metáforas com verbos iterativos e cursivos do Português Brasileiro e do Inglês", o qual faz parte do projeto de pesquisa intitulado "Regularidade interpretativa: o significado aspectual na interpretação das sentenças metafóricas verbais do Português Brasileiro e do Inglês", coordenado pela professora Dra. Dieysa Kanyela Fossile, procuramos (i) fornecer evidências de que os valores aspectuais podem influenciar na interpretação das ocorrências metafóricas que apresentam esses verbos; (ii) investigar se há (ir)regularidade interpretativa nas metáforas do Português Brasileiro e nas metáforas do Inglês e (iii) caracterizar a simetria entre a interpretação das metáforas do Português Brasileiro e a interpretação das metáforas do Inglês.

Utilizamos a metodologia elaborada por Moura (2007) e Fossile (2008a; 2008b; 2008c, 2011a, 2012b, 2012c) para a realização da análise descritiva e comparativa das ocorrências metafóricas do Português Brasileiro e do Inglês. Assim, obtivemos a partir da web, sentenças metafóricas com os verbos chicotear e varrer, bem como com o verbo cursivo caminhar. No Inglês, trabalhamos com os verbos to whip, to sweep e to speak.

Realizamos a análise e a descrição dos dados a partir da Teoria da Interação Semântica de Black (1993), pois a mesma atende tanto ao nível linguístico quanto ao nível cognitivo, enfatizando que a metáfora é um fenômeno especial em que os termos que compõem o enunciado interagem, simultaneamente, gerando uma operação mental, na perspectiva de que a linguagem cria realidades e formas de pensar (Fossile, 2008a, 2008b, 2008c, 2011a, 2011b, 2012b, 2012c; Dias e Fossile, 2014).

\section{UM POUCO SOBRE METÁFORA E TEORIA DA INTERAÇÃO SEMÂNTICA}


A perspectiva da Interação Semântica de Max Black (1993) nos proporciona uma explicação e um caminho de fácil acesso à compreensão da metáfora. Os caminhos misteriosos da metáfora, que estão sendo estudados, podem fazer com que tal suporte linguístico, que é a metáfora, não seja visto como uma figura de linguagem apenas, mas sim como um objeto transformador. Reforçamos que a apresentação da metáfora através da Teoria Interacionista consegue nos mostrar, [...] que não é apenas a similaridade de palavras que constitui a metáfora, mas sim, que ao produzirmos e/ou interpretarmos uma metáfora levamos em consideração [...] (a) a experiência de mundo que possuímos; (b) o contexto em que nos encontramos para a construção da metáfora e (c) a intenção de apresentar algo que não seria possível com termos literais.

Max Black ao aperfeiçoar os estudos de I. A. Richards a despeito da Interação Semântica nos mostra que por meio da interação entre dois elementos que compõem a sentença metafórica, tópico e veículo, podemos alcançar interpretações. Nesse caso, o que acontece é que

the marker of a metaphorical statement selects, emphasizes, suppresses, and organizes features of the primary subject by applying to it statements isomorphic with the members of the secondary subject's implicative complex. In the context of a particular metaphorical statement, the two subjects "interact" in the following ways: (a) the presence of the primary subject incites the hearer to select some of the secondary subject's properties; and (b) invites him to construct a parallel implication-complex that can fit the primary subject; and (c) reciprocally induces parallel changes in the secondary subject. ${ }^{2}$ (Black, 1993, p. 28).

Averiguamos que Black não dá espaço para as afirmações de que a metáfora é apenas a ação de substituirmos uma palavra por outra, como afirma Aristóteles. Desse modo a metáfora não é apenas ornamento, sendo importante que a mesma seja compreendida, por exemplo, pelos alunos da educação básica em sua essência, ou melhor, examinamos no decorrer desta pesquisa que é importante que os alunos compreendam como se dá o processo de interpretação da metáfora, já que a utilizamos constantemente, em diálogos pessoais e/ou profissionais, ao produzirmos um trabalho científico, dentre outras situações.

\footnotetext{
${ }^{2} \mathrm{O}$ marcador de um enunciado metafórico seleciona, enfatiza, suprime, e organiza recursos do assunto principal, aplicando a ele declarações isomorfas com os membros do sujeito secundário. No contexto particular de um enunciado metafórico, os dois assuntos "interagem", das seguintes formas: (a) a presença do objeto principal incita o ouvinte para selecionar algumas das propriedades do sujeito secundário; e (b) convida-o a construir uma implicação paralela que pode caber o tema principal; e (c) reciprocamente induz mudanças paralelas no assunto secundário. (Tradução nossa).
} 


\section{METODOLOGIA ADOTADA PARA A ANÁLISE DAS METÁFORAS VERBAIS}

Conforme apresentado na introdução deste artigo, fazemos uso da metodologia elaborada por Moura (2007) e Fossile (2008a, 2008b, 2008c, 2011a, 2012b, 2012c) para análise e descrição dos dados obtidos na $w e b^{3}$. Essa metodologia é formada por oito passos, no entanto, neste texto, faremos uso de apenas sete deles, uma vez que não apresentaremos, neste artigo, o sistema gravitacional concernente ao $8^{\circ}$ passo. Abaixo, apresentamos os passos a serem seguidos e suas funções.

$1^{\circ}$ PASSO: Definir uma categoria (nominal ou verbal) que ocorra na posição de veículo das metáforas a serem investigadas. 20 PASSO: Definir uma lista de itens lexicais pertencentes à categoria escolhida (construção da relação paradigmática). $3^{\circ}$ PASSO: Pesquisar na web ocorrências de metáforas com os itens lexicais (selecionados no $2^{\circ}$ passo) na posição de veículo. $4^{\circ}$ PASSO: Identificar, na análise de dados, classes de interpretação (conjuntos de paráfrases) que possam ser inferidas a partir dos dados, para cada item lexical analisado. $5^{\circ}$ PASSO: Identificar possíveis correlações entre classes de interpretação e relações sintagmáticas (construção das relações sintagmáticas). $6^{\circ}$ PASSO: Comparar as relações sintagmáticas dos diferentes itens lexicais obtidos no $5^{\circ}$ passo e identificar padrões de interpretação válidos para os diferentes itens. $7^{\circ}$ PASSO: Comparar o tipo combinatório ( $6^{\circ}$ passo) e os resultados alcançados através da análise e da descrição das metáforas do Português ao tipo combinatório ( $6^{\circ}$ passo) e aos resultados localizados por meio da análise e da descrição das metáforas do Inglês. Através dessa comparação verificamos se os padrões de interpretação identificados nas metáforas do Português Brasileiro apresentam alguma similaridade com os padrões de interpretação identificados nas metáforas do Inglês (isso quando os padrões de interpretação forem identificados).

\section{COMPREENDENDO OS VALORES ASPECTUAIS ITERATIVO E PONTUAL}

\footnotetext{
${ }^{3} \mathrm{O}$ corpus metafórico foi coletado exclusivamente da internet com a ajuda de sites de busca como o Google para comprovação de que as metáforas analisadas estão em uso na língua; e, portanto são dados reais. Os sites cujos dados foram retirados são de vários gêneros de escrita, tais como: blogs de poesias, com assuntos voltados às ciências, às notícias, sites de músicas, sites de pensamentos, entre outros.
} 
Segundo o dicionário Houaiss da língua portuguesa (2009), chicotear significa 1. bater com chicote, dar chicotadas; 2. castigar com chicote, açoitar. Ao desenvolvermos este estudo, percebemos que o verbo chicotear possui certa maleabilidade que nos permite criar sentenças metafóricas pontuais e reiteradas. Isso parece ocorrer também com o verbo varrer.

Apresentamos a seguir, nos quadros 01 e 02, a representação gráfica dos valores aspectuais iterativo e pontual elaborados por Fossile (2012a, p. 88), desse modo podemos compreender como funciona o desenrolar da ação nos verbos analisados, chicotear e varrer.

(a) Representação gráfica do valor aspectual iterativo:

Quadro 01: Valor Aspectual Iterativo

Frame 01: Iterative Aspectual Value

(------) [chicotear+chicotear+chicotear+chicotear+chicotear+chicotear](------)

Fossile (2012a, p. 87) afirma que "o aspecto iterativo se realiza na fase medial, por isso essa fase é destacada no diagrama. Os sinais de adição mostram que há a repetição de uma mesma situação".

(b) Representação gráfica do valor aspectual pontual:

Quadro 02: Valor Aspectual Pontual

Frame 02: Timely Aspectual Value

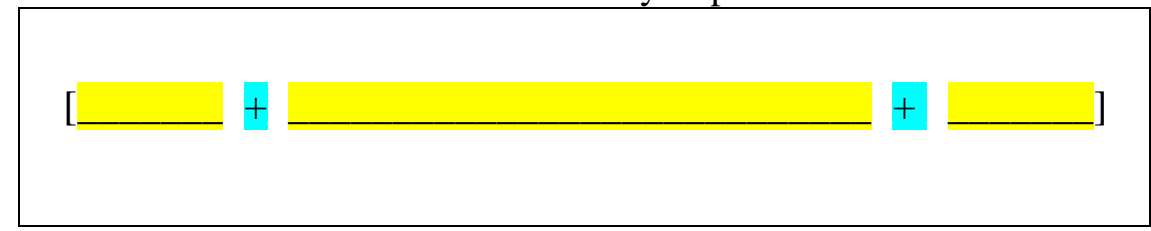

A autora nos esclarece que

por meio dos três espaços entre colchetes, sinalizados em amarelo [no quadro 02, tenta-se] representar as fases inicial, medial e final [do valor aspectual pontual]. O sinal de adição, destacado com a cor azul, entre os traços indicadores das fases representa que as mesmas ocorrem quase simultaneamente. (Fossile, 2012a, p. 87).

Uma vez entendida a atuação do verbo chicotear e varrer não apenas como iterativa, mas também como pontual, torna-se mais compreensível o estudo a seguir ${ }^{4}$.

\footnotetext{
${ }^{4}$ Os verbos to whip e to sweep serão analisados pela mesma perspectiva que os verbos chicotear e varrer.
} 


\section{DESCRICÃO E ANÁLISE DOS DADOS}

\section{Descrição e análise de metáforas com o verbo chicotear}

$\mathrm{Na}$ análise do corpus $^{i}$ adquirido, isto é, nas metáforas com o verbo chicotear na posição de veículo e com tópicos de diferentes classes semânticas, nós identificamos as seguintes interpretações: a) bater e b) manifestar. Para a sentença metafórica (1) entendemos que a onda bateu no edifício. Na sentença (2) depreendemos que o frio vai se manifestar em São Joaquim. Na metáfora (3) compreendemos que um vento gelado bateu em seu cabelo. Na sentença (4) concluímos que uma rajada de vento bateu nas cortinas. Na sentença metafórica (5) entendemos que uma forte rajada de vento bateu em sua face. Na sentença (6) depreendemos que uma forte rajada de vento bateu na poeira do chão do vale. Na sentença metafórica (7) compreendemos que mais uma rajada de vento bateu contra nós. Na metáfora (8) concluímos que uma grande tempestade manifestou-se no oceano em fúria. Na sentença metafórica (9) entendemos que a tempestade manifestou-se na montanha toda a noite. Na metáfora (10) depreendemos que a tempestade da semana passada manifestou-se em Kansas City. Na sentença (11) concluímos que a tarde serve para manifestar-se em nossa miséria. Na sentença metafórica (12) analisamos que a onda de poeira bateu em nós. Na metáfora (13) depreendemos que relâmpagos manifestam-se nos céus. Na metáfora (14) concluímos que um relâmpago manifestou-se, lançando uma luz azul. Na sentença (15) entendemos que um relâmpago bateu no solo próximo aos pés de Hermes. Na sentença (16) depreendemos que o mar, bravio, batia nos rochedos das encostas. Na metáfora (17) concluímos que um relâmpago manifestou-se ao longe. Na sentença metafórica (18) analisamos que o céu manifestava seus poemas em maravilha pura. Na sentença (19) depreendemos que se uma ventania bater em uma duna, em um precipício de 45 graus, as chances dela deslizar são grandes. Para a sentença metafórica (20) vemos que a ventania manifestou-se, intrusa ao clímax.

Ao analisarmos as sentenças metafóricas de (1) a (20) percebemos que o valor aspectual iterativo parece estar inerente ao lexema verbal (cf. Fossile, 2008a, 2008b, 2008c, 2012b, 2012c, 2011a; Dias e Fossile, 2014). O valor aspectual iterativo e pontual parece predominar em algumas ocorrências metafóricas analisadas por causa (i) da interação entre o tópico e o veículo da metáfora, (ii) do próprio tópico que contribui para que a noção de pontualidade se sobressaia e (iii) do contexto linguístico. É na interação do tópico e do veículo, elementos que 
formam a metáfora, que compreendemos o insight cognitivo, que produzimos ao interpretarmos uma metáfora.

Destacamos que o significado aspectual iterativo parece estar inerente ao radical do verbo chicotear, isto é, chicot-, assim como no estudo inicial realizado no período de agosto de 2012 a julho de $2013^{5}$; pois, o mesmo está presente em todas as sentenças metafóricas verbais, mesmo que as flexões verbais variem (Dias e Fossile, 2014). Desse modo, verificamos, a partir desta pesquisa, que o que determinará se o verbo chicotear assumirá o valor aspectual iterativo ou pontual será a interação entre o tópico e o veículo da metáfora, o próprio tópico, as experiências de mundo do emissor e/ou receptor da sentença metafórica em questão e ainda o contexto linguístico em que a metáfora está inserida. Esses elementos é que determinam qual aspecto será considerado mais expressivo. Por fim, percebemos que o sentido literal também interfere na busca pela interpretação da metáfora (Cf. Fossile, 2008a, 2008b, 2008c, 2012b, 2012c, 2011a; Dias e Fossile, 2014). Portanto, observando os resultados, percebemos que nas interpretações das sentenças metafóricas com os verbos chicotear e varrer, em dados momentos notamos a presença do valor aspectual pontual, e em outros, a presença do valor iterativo.

O quadro $03^{6}$ apresenta o tipo combinatório para as metáforas cujo elemento comum é a noção de valor aspectual iterativo e de valor aspectual pontual, representando assim os verbos: chicotear, varrer, to sweep e to whip.

Quadro 03 - Tipo combinatório de metáfora com verbo de situação iterativa.

Table 03 - Combinatorial type of metaphor with iterative situation verb.

\section{Tipo de metáfora com verbo de situação iterativa}

\begin{tabular}{l|l|l} 
[TÓPICO $(\mathrm{X})$ & + & VEÍCULO (verbo de situação iterativa $a_{\mathrm{v}}$ )]
\end{tabular}

(i) Paráfrase $=$ valor aspectual pontual $\mathrm{I}_{\mathrm{v}}$

(ii) Paráfrase $=$ valor aspectual iterativo $\mathrm{v}_{\mathrm{v}}$

\section{Descrição e análise de metáforas com o verbo varrer}

A seguir, apresentamos ocorrências metafóricas com o verbo varrer na posição de veículo. Ao analisarmos o corpus coletado, isto é, as metáforas com o verbo varrer, identificamos as classes de interpretação: a) excluir/tirar, b) destruir e c) manifestar. Para a

\footnotetext{
${ }^{5}$ Descrevendo e analisando metáforas do Português Brasileiro e do Inglês com verbos iterativo e cursivo.

${ }^{6}$ Utilizamos o mesmo quadro para representar o tipo combinatório de metáfora com os verbos chicotear, varrer, to sweep e to whip.
} 
sentença metafórica (21) compreendemos que a ventania destruiu a praça João Lisboa. A sentença (22) analisamos que a ventania destruiu Seattle! Na metáfora (23) concluímos que uma intensa ventania destruiu Rolandia. Para a sentença metafórica (24) depreendemos que a ventania destruiu Canoas. Na sentença (25) concluímos que uma forte ventania destruiu Aracaju. Na metáfora (26) vemos que uma ventania manifestou-se (n)o local, fazendo Hermione cair de costas. Para a sentença metafórica (27) analisamos que a ventania invadiu e destruiu, jogando tudo pro ar. Na sentença (28) analisamos que a ventania destruiu a região na noite da última quarta-feira. Para a sentença metafórica (29) depreendemos que uma violenta rajada de vento destruiu parte do litoral norte de Maceió. Na metáfora (30) concluímos que uma forte ventania destruiu o lugar. Para a sentença metafórica (31) vemos que a ventania manifestou-se em barafunda. Na sentença (32) compreendemos que uma ventania destruiu tudo. Na metáfora (33) analisamos que uma súbita ventania destruiu a entrada do quartel. Para a sentença metafórica (34) concluímos que uma ventania excluiu/tirou todas as sementes do armazém. Na sentença (35) depreendemos que a ventania começou a excluiu/tirou os galhos e folhas das árvores. Na metáfora (36) analisamos que a chuva de vento excluiu/tirou o que havia no quintal. Para a sentença metafórica (37) vemos que a ventania excluiu/tirou o amarelo do céu. Na sentença (38) compreendemos que a ventania manifestou-se nas vidraças. Na metáfora (39) chegamos à conclusão de que a ventania que destruiu Brasília é sinal de que vem muita água por aí. Para a sentença metafórica (40) percebemos que amostra estética da onda 'glam' que destruiu a Grã-Bretanha nos 70. Na sentença (41) vemos que enorme onda que destruiu antiga civilização terrestre. Na metáfora (42) concluímos que a sequência de tragédia dos incêndios florestais destruíram Portugal. Para a sentença metafórica (43) analisamos que dezenas de tornados destruíram o Meio-Oeste americano. Na sentença (44) concluímos que as inundações não destruíram o país no inverno. Na sentença (45) analisamos que a ventania manifestou-se em barafunda. Na metáfora (46) concluímos que veio uma ventania do Freeport Outlet de Alcochete que destruiu tudo. Para a sentença metafórica (47) compreendemos que as ondas excluíram/tiraram tudo para o interior. Na sentença (48) analisamos que os maremotos destruíram os continentes. Na metáfora (49) vemos que a mulher arrumou a casa e excluiu/tirou ditaduras. Para a sentença metafórica (50) percebemos que tudo foi consequência dos fortes incêndios florestais que destruíram o país. Na sentença (51) depreendemos que as ondas destruíram o Índico e 230.000 vidas. Na metáfora (52) concluímos que ventos fortes destruíram a Holanda. Para a sentença metafórica (53) chegamos à conclusão de que o vendaval destruiu o concelho logo pela manhã. Na sentença 
(54) percebemos que os ventos fortes destruíram região de rio maior. Na metáfora (55) analisamos que os ventos de $80 \mathrm{~km}$ destruíram a cidade. Na metáfora (56) analisamos que as duas grandes ondas destruíram a Ásia Oriental e Sudeste Asiático. Para a sentença metafórica (57) concluímos que ela veio para excluir/tirar as emoções. Na metáfora (58) vemos que [Ela] excluiu/tirou a alegria. Para a sentença metafórica (59) vemos que um vento excluiu/tirou a alegria. Na sentença (60) percebemos que o tsunami destruiu minha vida. Na metáfora (61) depreendemos que as guerras de Esporos destruíram todas as pessoas.

Ao interpretarmos as metáforas de (21) a (61), levamos em consideração o contexto linguístico, tal como a interação entre o tópico e o veículo das sentenças analisadas. Dessa maneira, também verificamos que o sentido metafórico está associado ao sentido literal do verbo varrer (cf. Fossile, 2008a, 2008b, 2008c, 2011a, 2012b, 2012c; Dias e Fossile, 2014). A

partir da interpretação das sentenças metafóricas de (21) a (61) percebemos que a pontualidade e a iteratividade acontece por causa da interação entre o tópico e o veículo, e por causa do contexto linguístico. Vemos que nas interpretações alcançadas há, em vários casos, a presença do valor aspectual pontual. Conforme observado nos estudos de Fossile (2008a, 2008b, 2008c, 2011a, 2012b e 2012c), o tópico e o veículo de uma sentença metafórica não agem de maneira independente, pois é necessário que haja uma interação entre os mesmos para que se chegue a um insight.

\section{Descrição e análise de metáforas verbais com valor aspectual cursivo, especificamente, com o verbo caminhar}

A seguir, apresentamos ocorrências metafóricas com o verbo caminhar. $\mathrm{Na}$ análise do corpus com o verbo caminhar encontramos a classe de interpretação: a) seguir. Para a sentença metafórica (62) percebemos que o amor segue pelo caminho da verdade. $\mathrm{Na}$ sentença (63) concluímos que o amor segue em sentido anti-horário. Na metáfora (64) depreendemos que para onde segue o amor? Para a sentença metafórica (65) analisamos que o amor segue juntamente com a dor. Na sentença (66) chegamos à conclusão de que o amor segue ao lado do perdão. Na metáfora (67) concluímos que o amor e o perdão seguem lado a lado. Na sentença (68) percebemos que o amor segue no rastro da sexualidade. Na metáfora (69) analisamos que o amor segue ao lado. Na sentença (70) chegamos à conclusão de que nem sempre a paixão segue rumo ao amor. Na metáfora (71) percebemos que a paixão segue 
para qualquer parte do mundo. Para a sentença metafórica (72), que é título de um texto esportivo, chegamos à seguinte interpretação: no Futebol: para onde segue a paixão?

Novamente, analisamos as sentenças de (62) a (72) considerando o contexto linguístico tal como a interação entre o tópico e o veículo de cada metáfora. Conforme observado em pesquisas anteriores, tal como, nos estudos de Fossile (2008a, 2008b, 2008c, 2011a, 2012b, 2012c; Dias e Fossile, 2014), percebemos, novamente, que o valor aspectual cursivo ${ }^{7}$ parece estar inerente ao radical do verbo, neste caso, caminh-, e que dependendo da flexão verbal tal aspectualidade acaba sendo reforçada ou não. Com isso percebemos que a paráfrase obtida se relaciona com o sentido literal do verbo caminhar.

Também observamos que ao interpretarmos uma sentença metafórica verbal a interação entre o tópico e o veículo é de fundamental importância, pois ela reforça a ideia da aspectualidade presente no contexto da sentença. O sentido literal, assim como nos demais verbos, também influencia na busca pela paráfrase mais adequada. (Fossile, 2008a, 2008b, 2008c, 2011a, 2012b, 2012c; Dias e Fossile, 2014).

O verbo caminhar, assim como o verbo dançar, possui forte indício de que o valor aspectual cursivo esteja inerente no seu radical. Isso não impede que outro valor aspectual possa estar presente nas metáforas analisadas, contudo, nenhum outro aspecto verbal mostrouse em destaque nas nossas análises aqui realizadas (cf. Fossile, 2008a, 2008b, 2008c, 2011a, 2012b, 2012c; Dias e Fossile, 2014). A partir dessas afirmações, concluímos que a interação entre o tópico e o veículo contribui na busca pela interpretação mais adequada. E podemos reafirmar, ainda, que "a noção aspectual cursiva [parece que] está relacionada ao conteúdo semântico do verbo". (Dias e Fossile, 2014, p. 116).

\section{Descrição e análise de metáforas com o verbo to whip}

Apresentamos agora as ocorrências metafóricas com o verbo to whip na posição de veículo. Desta maneira encontramos a classe de interpretação manifestar. Na sentença (73) chegamos à conclusão de que ventos se manifestam Minnesota. Na metáfora (74) depreendemos que forte tempestade se manifestou ao norte da Europa. Para a sentença metafórica (75) concluímos que uma forte tempestade se manifestou nas ondas monstruosas

\footnotetext{
${ }^{7}$ É o aspecto caracterizado, na Língua Portuguesa, por expressar cursividade. Esclarecemos que cursividade é uma noção aspectual predominante em situações que se apresentam em desenvolvimento pleno, isto é, tendo ultrapassado os seus momentos iniciais e ainda não tendo alcançado os seus momentos finais. (Fossile, 2012a).
} 
em um frenesi de águas bravas. Na sentença (76) depreendemos que forte tempestade se manifestou na área. Na metáfora (77) concluímos que a tempestade se manifestou nos últimos flocos de neve através do extremo norte da Nova Inglaterra. Para a sentença metafórica (78) analisamos que a tempestade se manifestou no estado com chuva intensa. Na sentença (79) vemos que um tornado se manifestou na cidade do Nicaragua, afetando 2000 pessoas. $\mathrm{Na}$ metáfora (80) vemos que, tempestades se manifestam em Nicaragua. Para a sentença metafórica (81) concluímos que uma tempestade de poeira se manifestou no Oriente Médio.

Ao interpretarmos as metáforas de (73) a (81) com o verbo to whip percebemos algumas semelhanças com a análise realizada com as metáforas com verbos iterativos no Português Brasileiro, tais como: a) o valor aspectual iterativo parece estar inerente ao lexema verbal (cf. Fossile, 2008a, 2008b, 2008c, 2011a, 2012b, 2012c; Dias e Fossile, 2014); b) o valor aspectual iterativo ocorre por causa da interação entre o tópico e o veículo da metáfora, do próprio tópico e do contexto linguístico.

\section{Descrição e análise de metáforas com verbo to sweep}

Ao analisar metáforas com o verbo to sweep na posição de veículo, conseguimos identificar a classe de interpretação manifestar. Na sentença (82) concluímos que ventos fortes se manifestam nas cidades gêmeas do centro-sul do Minnesota na sexta-feira à noite e sábado de manhã cedo. Na metáfora (83) depreendemos que fortes tempestades se manifestaram no noroeste da Indiana. Para a sentença metafórica (84) analisamos que os fortes ventos se manifestam na Grã-Bretanha. Na sentença (85) concluímos que os ventos fortes se manifestam no metrô Detroit. Na metáfora (86) depreendemos que ventos cortantes se manifestam ao leste no despertar da tempestade de neve. Para a sentença metafórica (87) chegamos à conclusão de que os ventos fortes de Sven se manifestam no sul da Suécia. Na sentença (88) analisamos que ventos fortes se manifestam em toda área metropolitana de Atlanta. Na metáfora (89) vemos que tempestades se manifestam no metrô de Atlanta. Para a sentença metafórica (90) concluímos que fortes chuvas e ventos de até $128,7 \mathrm{k} / \mathrm{h}$ irão se manifestar em todo o país. Na sentença (91) depreendemos que ventos fortes se manifestam ao oeste de Midlands. Na metáfora (92) ventos fortes se manifestam Dallas-Fort Worth. Para a sentença metafórica (93) analisamos que mais rajadas de ventos se manifestam no centro de Iowa. Na sentença (94) percebemos que ventos frios se manifestam ao redor. Na metáfora (95) concluímos que ventos fortes que se manifestam no sul da Califórnia. Para a sentença 
metafórica (96) percebemos que ventos fortes se manifestam em todo o sul do Reino Unido. Na sentença (97) analisamos que há perigo de fogo por conta dos ventos que se manifestam em SoCal. Na metáfora (98) chegamos à conclusão de que o vento se manifestou na cidade. Para a sentença metafórica (99) percebemos que ventos fortes se manifestam em Hull e East Riding. Na sentença (100) depreendemos que ventos fortes se manifestam no Centro-Oeste. Na metáfora (101) vemos que ventos fortes se manifestam no Norte e na Escócia. Para a sentença metafórica (102) depreendemos que ventos frios se manifestam em Ventura County. $\mathrm{Na}$ sentença (103) analisamos que ventos fortes que se manifestam em Surrey e Sussex. Na metáfora (104) concluímos que ventos fortes se manifestam no estado. Para a sentença metafórica (105) analisamos que ventos fortes se manifestam no Centro-Oeste. Na sentença (106) percebemos que ventos fortes se manifestam em área da baía. Na metáfora (107) concluímos que os ventos se manifestam em Dorset. Para a sentença metafórica (108) concluímos que ventos fortes se manifestam em Auckland. Na sentença (109) percebemos que ventos do noroeste se manifestam em meio a milhares de aves de rapina em Hawk Mountain. Na metáfora (110) analisamos que é bom sentir o vento se manifestar em seu cabelo quando você monta sua scooter. Para a sentença metafórica (111) vemos que um homem é levantado do chão, por causa dos ventos fortes que se manifestam em Sennen Cove, Cornwall. Na sentença (112) depreendemos que tempestades se manifestam em toda a Grã-Bretanha. Na metáfora (113) concluímos que tornados e tempestades mortais se manifestam no centro e o sul dos Estados Unidos. Para a sentença metafórica (114) vemos que tempestade se manifesta em Gretna nas finais da EMC. Na metáfora (115) concluímos que tempestades se manifestam nos estados do centro e do sul. Para a sentença metafórica (116) analisamos que fortes tempestades se manifestam no meio oeste e o sul. Na sentença (117) compreendemos que tempestades se manifestam em Great Plains, trazendo ventos fortes. Na metáfora (118) analisamos que o vento se manifestou no lago meio congelado. Para a sentença metafórica (119) concluímos que tempestades poderosas se manifestam em Area Overnight.

$\mathrm{Na}$ interpretação das sentenças metafóricas de (82) a (119) levamos em consideração o contexto linguístico, assim como nos demais dados, ou seja, observamos prioritariamente o tópico e o veículo de cada metáfora. Com isso, averiguamos que o sentido metafórico está associado ao sentido literal do verbo to sweep, tal como ocorreu com as metáforas do PB, acima analisadas. Analisando o verbo to sweep, percebemos a presença do valor aspectual iterativo como elemento comum encontrado nas interpretações das sentenças metafóricas. Ressaltamos que uma quantidade muito maior de dados precisa ser analisada para que seja 
apresentada uma análise mais precisa do estudo elaborado até o momento.

\section{Descrição e análise de metáforas com verbo to speak}

Ao analisarmos o corpus, identificamos a paráfrase expressar-se. Na sentença (120) compreendemos que a alma se expressa. Na metáfora (121) concluímos que a alma pode se expressar. Para a sentença metafórica (122) percebemos que a alma se expressa. Na sentença (123) analisamos que a alma se expressa em linguagem colorida. Na metáfora (124) vemos a alma se expressa. Para a sentença metafórica (125) depreendemos que a alma se expressa por meio das imagens. Na sentença (126) chegamos à conclusão de que nossa alma se expressa por si mesma. Na metáfora (127) concluímos que a alma fala através da saudade. Para a sentença metafórica (128) compreendemos que a alma se expressa de forma misteriosa. $\mathrm{Na}$ sentença (129) vemos que a alma se expressa.

Dessa maneira durante a análise das sentenças metafóricas de (120) a (129) cujo tópico é soul, conseguimos observar que a paráfrase relaciona-se ao sentido literal. E assim como realizado na análise do verbo caminhar, levamos em consideração o contexto linguístico e a interação entre o tópico e o veículo de cada metáfora. Percebemos também, conforme observado nos estudos acima citados, que o valor aspectual cursivo parece estar inerente ao radical do verbo, isto é, to speak. E por fim, vemos que o contexto das sentenças metafóricas, a experiência de mundo que o emissor e/ou receptor possui, bem como a carga aspectual presente no próprio tópico intervém na busca pela interpretação da metáfora verbal em questão.

Desde os estudos de Fossile (2008a, 2008b, 2008c, 2011a, 2012b e 2012c), o valor aspectual cursivo tem se mostrado bastante singular nas metáforas analisadas com esse verbo, isto é, metáforas com esse verbo não apresentaram até o momento indícios que fizessem alusão a outro valor aspectual. Os elementos que levamos em consideração para a interpretação das metáforas foram: o tópico, o radical do verbo da metáfora, a interação entre tópico e veículo, o conhecimento de mundo e contexto linguístico. Esses elementos não abriram, até o momento, espaço para que outro valor aspectual pudesse interferir na interpretação.

Deste modo, com a análise e a descrição realizadas vemos a presença do valor aspectual cursivo como elemento comum nas interpretações. Reafirmamos, ainda, que há "forte indício 
de que o aspecto verbal cursivo esteja inerente ao radical do termo dançar [to dance, caminhar e to speak], o qual faz parte do veículo das metáforas analisadas" (DIAS e FOSSILE, 2014, p. 116), porém isso não impede que valores aspectuais diferentes estejam presentes nas metáforas analisadas (Fossile, 2008a, 2008b, 2008c, 2011a, 2012b e 2012c).

\section{CONSIDERAÇÕES FINAIS: UMA SÍNTESE PARA A INTERPRETAÇÃO DAS METÁFORAS}

Analisamos um corpus total de 129 metáforas do Português Brasileiro e do Inglês. A partir das análises e descrições realizadas percebemos que certas regularidades encontradas no Português Brasileiro também foram encontradas no Inglês, mostrando que as metáforas não são interpretadas de maneira casual e aleatória. Dentre tais regularidades vemos que: a) a interação entre o tópico e o veículo da metáfora é o ponto mais importante na busca pela paráfrase, pois a interação entre os dois elementos interferiu de maneira significativa na interpretação das metáforas; b) os tópicos são muito importantes para uma boa interpretação das sentenças metafóricas, pois eles também reforçam o valor aspectual que está presente no veículo da sentença metafórica; c) o contexto linguístico e experiência de mundo também nos guiam para a paráfrase mais adequada; d) o sentido literal influência na busca pela paráfrase mais adequada; e f) o valor aspectual parece ser expresso pelo radical do verbo e não unicamente por flexões verbais.

Concluímos com este estudo que há regularidade ao interpretarmos metáforas do Português Brasileiro e do Inglês e que ao interpretarmos uma metáfora não a interpretamos de maneira casual e aleatória, pois elementos como o tópico, o veículo da metáfora, o contexto em que a metáfora foi criada e/ou absorvida podem influenciar de maneira considerável na interpretação.

\section{REFERÊNCIAS}

DIAS, T. S.; FOSSILE, D. K. 2014. Aspectualidade: metáforas do PB e do Inglês com verbos iterativos e cursivos. In: PIBIC 2013 - Melhores Trabalhos do IX Seminário de Iniciação Científica da universidade Federal do Tocantins. (Orgs.) Maria José de Pinho, Halisson Queiroz, Michelle Araújo Luz Cilli. Palmas: Universidade Federal do Tocantins. EDUFT, p. 107-125.

FOSSILE, D. K. 2008a. Interpretação de metáforas com verbos de mudança de estado. Revista Ciências e Cognição. Rio de Janeiro, v. 13, n. 3, p. 187-198.

2008b. Regularidade Interpretativa nas metáforas com verbos de mudança de estado.

Revista Línguas e Letras. Cascavel, v. 9, n. 16, p. 37 - 66. 
2008c. Metáforas com verbos de mudança de estado. Dissertação (Mestrado em Letras/Linguística) - Curso de Pós-Graduação em Letras/Linguística, Universidade Federal de Santa Catarina, p. 90.

2011a. O Significado Aspectual na Interpretação de Metáforas Verbais. Tese (Doutorado em Letras/Linguística) - Curso de Pós-Graduação em Letras/Linguística, Universidade Federal de Santa Catarina, p. 300.

$2011 b$.

Um passeio pelos estudos da metáfora. Revista de Letras. Curitiba, n. 14, p.01 - 15,

. 2012a. Valores Aspectuais do Português Brasileiro e do Alemão: Uma Proposta de Síntese. In: H. M. de M. MOURA; M. B. MOTA; A. P. de O. SANTANA (1.ed), Cognição, Léxico e Gramática. Florianópolis: Insular, p. 1-32.

2012b. Descrevendo, analisando, interpretando e comparando metáforas do Português Brasileiro (PB) e do Alemão. Revista Signum: Estudos de Linguagem. , v. 15, n. 3, p. $171-193$.

2012c. Metáforas da Língua Alemã com verbos inceptivos e cursivos: influência do significado aspectual na interpretação. Fórum Linguistico (Online). , v. 9, n. 3, p. 159 - 179.

HOUAISS, A.; VILLAR, M. de S. Dicionário Houaiss da língua portuguesa. 1. Ed. Rio de Janeiro: Objetiva, 2009.

LAKOFF. G.; JOHNSON. M. 1980. Metaphor we live by. Chicago: University of Chicago Press. p. 256.

MOURA, H. M. M. 2007. Relações paradigmáticas e sintagmáticas na interpretação de metáforas. Linguagem em discurso, Tubarão, v. 7, n. 3.

\footnotetext{
${ }^{\mathrm{i}}$ Apresentamos, aqui, os links de onde retiramos os dados analisados. Assim, a sentença metafórica (1) está disponível em: http://pt.dreamstime.com/fotos-de-stock-onda-chicoteou-o-edifcio-image9350203 Acesso em: 14-01-14.; A metáfora (2) está disponível em: http://saojoaquimonline.com.br/saojoaquimdefato/?p=7292 Acesso em: 14-09-14; A sentença metafórica (3) está disponível em: http://bloglivroson-

line.blogspot.com.br/2011/06/capitulo-16.html Acesso em: 14-01-14; A metáfora (4) está disponível em: http://www.multiajuda.com.br/livro.php?id=18194\&n=Mestre+da+Montanha Acesso em: 14-01-14; A metáfora (5) está disponível em: http://fanfiction.com.br/historia/104367/Saga_Sillentya_Lagrimas da_Alma/capitulo/23/ Acesso em: 14-014; A sentença (6) está disponível em: http://thoth3126.com.br/os-cavaleiros-templarios-e-aarca-da-alianca-parte-8/ Acesso em: 14-01-14; A metáfora (7) está disponível em:

http://socialspirit.com.br/fanfics/historia/fanfiction-one-direction-the-whistler-1322836/capitulo4 Acesso em: 14 01-14; A sentença (8) está disponível em: http://tirtairnge.blogspot.com.br/2012/01/chegada-de-angus-ebride.html Acesso em: 14-01-14; A metáfora (9) está disponível em:

http://www.academia.org.br/abl_e4w/cgi/cgilua.exe/sys/start.htm?infoid=12825\&sid=97 Acesso em: 14-01-14; A metáfora (10) está disponível em: http://m.g1.globo.com/mundo/noticia/2013/02/segunda-tempestade-deneve-provoca-novos-estragos-nos-eua.html Acesso em: 14-01-14; A sentença metafórica (11) está disponível em: http://www.correiodopovo.com.br/blogs/juremirmachado/?p=4062 Acesso em: 14-01-14; A sentença (12) está disponível em: http://input666.wordpress.com/tag/tempestade-de-areia/ Acesso em: 14-01-14; A sentença (13) está disponível em: http://www.vagalume.com.br/krisiun/descending-abomination-traducao.html Acesso em: 14-01-14 ; A metáfora (14) está disponível em: http://socialspirit.com.br/fanfics/historia/fanfiction-misccross-overs-um-caso-em-reclusao-317251/capitulo1 Acesso em: 14-01-14; A sentença metafórica (15) está disponível em: http://www.recantodasletras.com.br/contosdeficcaocientifica/4222637 Acesso em: 14-01-14; A sentença (16) está disponível em: http://www.wattpad.com/20938134-estrela-em-busca-do-amor-eternopr\%C3\%B3logo-parte-2 Acesso em: 14-01-14; A metáfora (17) está disponível em:

http://z13.invisionfree.com/Decadium_Wars/index.php?showtopic=127 Acesso em: 14-01-14; A sentença (18) está disponível em: http://www.radio.uol.com.br/\#/letras-e-musicas/bob-dylan/chimes-of-freedom/2473384 Acesso em: 14-01-14; A sentença (19) está disponível em: http://gooutside.dominiotemporarioidc.com/1151 Acesso em: 10/02/2014; A sentença (20) está disponível em:

https://www.google.com.br/search?q=A+ventania+bateu\%2C+intrusa+ao+cl\%C3\%ADmax \%2C\&oq=A+ventan ia+bateu $\% 2 \mathrm{C}+$ intrusa+ao+cl\%C3\%ADmax \%2C\&aqs=chrome..69i57j69i59.835j0j4\&sourceid=chrome\&espv=2 10\&es_sm=122\&ie=UTF-8\#q=a+ventania+chicoteou Acesso em: 10/02/2014. A metáfora (21) está disponível em: http://elo.com.br/portal/noticias/ver/139301/ventania-destroi-presepio-da-praca-joao-lisboa.html Acesso em: 18/09/13; A sentença metafórica (22) está disponível em: http://daisyuw.blogspot.com.br/2008/10/e-que-
} 
ventania.html Acesso em: 18/09/13; A sentença (23) está disponível em:

http://www.climatempo.com.br/olhonotempo/75467/chuva Acesso em: 08/09/13; A sentença metafórica (24)

está disponível em: http://www.diariodecanoas.com.br/clima/360122/canoas-contabiliza-estragos-apos-o-

vendaval-de-quarta-feira.html Acesso em: 18/09/13; metáfora (25) está disponível em:

http://www.clicksergipe.com.br/blog.asp?pagina=1\&postagem=7850 Acesso em: 18/09/13; A sentença (26) está disponível em: http://www.fanfiction.net/s/3627351/3/Os-dispostos-se-atraem Acesso em: 18/09/13; A sentença metafórica (27) está disponível em: http://www.vagalume.com.br/cris-aflalo/finzinho-da-chuva.html Acesso em: 21/01/2014; A metáfora (28) está disponível em:

http://bjd.com.br/site/noticia.php?id_editoria=8\&id_noticia=7508 Acesso em: 21/01/2014; A sentença metafórica (29) está disponível em: http://nh1.ne10.uol.com.br/noticia/maceio/2013/04/25/242525/ventania-naorla-arrasta-tendas-e-adia-circuito-da-lua-ze-aprigio-vilela Acesso em: 18/09/13; A sentença metafórica (30) está disponível em: http://www.mrmalas.com/lendas/lenda.asp?id=14515 Acesso em: 18/09/13; A sentença (31) está disponível em: http://visao.sapo.pt/e-se-de-repentenao-houvesse-adultos=f618966\#ixzz2fGpas94f Acesso em: 18/09/13; A sentença (32) está disponível em: http://www.fotolog.com.br/40_amelia/8317395/ Acesso em: 18/09/13; A metáfora (33) está disponível em:

http://www.militar.com.br/modules.php?name=Historia\&file=display\&jid=125 Acesso em: 18/09/13; A sentença metafórica (34) está disponível em:

http://kids.sapo.pt/descobrir/historias/historia_do_dia/artigo/os_dois_primos_li Acesso em: 18/09/2013; A sentença (35) está disponível em: http://mariaescrevinhadora.blogspot.com.br/2010/05/amanhecer.html Acesso em: 18/09/2013; A metáfora (36) está disponível em:

http://mariaescrevinhadora.blogspot.com.br/2010/05/amanhecer.html Acesso em: 18/09/2013; A sentença (37) está disponível em:

https://www.facebook.com/permalink.php?id=281060821916299\&story fbid=649318648423846 Acesso em: 03/12/2013; A sentença (38) está disponível em: http://senhoradosul.blogspot.com.br/2004/10/ventania.html Acesso em: 03/12/2013; A sentença metafórica (39) Disponível em:

https://www.google.com.br/\#q=ventania+varreu\&start=10 Acesso em: 03/12/2013; A metáfora (40) está disponível em:

http://www.bbc.co.uk/portuguese/celular/noticias/2013/02/130210_galeria_glam_exposicao_cc.shtml Acesso em: 09/12/2013; A sentença (41) está disponível em: http://www.linguee.com.br/portugues-

ingles/traducao/varreu.html Acesso em: 09/12/2013; A sentença metafórica (42) está disponível em: http://glosbe.com/pt/en/varreram Acesso em: 09/12/2013; A sentença (43) está disponível em: http://www.dicio.com.br/varreram/ Acesso em: 09/12/2013; A sentença (44) está disponível em: http://glosbe.com/pt/en/varreram Acesso em: 09/12/2013; A sentença metafórica (45) está disponível em: http://visao.sapo.pt/e-se-de-repentenao-houvesse-adultos=f618966\#ixzz2fGpas94f Acesso em: 18/09/13; A sentença (46) está disponível em: http://www.fotolog.com.br/40_amelia/8317395/ Acesso em: 18/09/13; A sentença (47) está disponível em: http://www2.uol.com.br/sciam/reportagens/onda_de_mudanca_5.html Acesso em:18/12/2013; A metáfora (48) está disponível em: http://glosbe.com/pt/en/varrera Acesso em: 18/12/2013; A sentença metafórica (49) está disponível em: http://cruzeiro.org/blog/a-mulher-que-pulverizou-ditaduras/ Acesso em: 13/02/2014; A sentença (50) está disponível em: http://glosbe.com/pt/en/varreram Acesso em: 09/12/2013; A metáfora (51) está disponível em: http://www.acorianooriental.pt/noticias/ver/198104 Acesso em: 18/12/2013; A sentença (52) está disponível em: http://www.dicio.com.br/varreram/ Acesso em: 09/12/2013; A sentença (53) está disponível em:

https://www.facebook.com/permalink.php?id=399457500101727\&story_fbid=622099597837515 Acesso em: 18/12/2013; A sentença (54) está disponível em: http://videos.sapo.pt/llShHWeIMlZQnMtS8ty7Acesso em: 18/12/2013; A metáfora (55) está disponível em: http://www.divinews.com/cidade/saude/11631.html Acesso em: 18/12/2013; A sentença (56) está disponível em: http://pt.wikipedia.org/wiki/Onda_Revolucion\%C3\%A1ria Acesso em: 09/12/2013; A metáfora (57) está disponível em:〈http://www.overmundo.com.br/banco/ela-13〉. Acesso em: 10/12/2012; A sentença (58) está disponível em: http://letras.mus.br/ribero/1844307/ Acesso em:21/01/2013; A metáfora (59) está disponível em:

http://www.recantodasletras.com.br/sonetos/3298858Acesso em:21/01/2013; A sentença (60) está disponível em: http://www.porqueeueumoutro.blogspot.com.br/ Acesso em: 21/01/2013; A sentença metafórica (61) está disponível em: http://trocandoconceitos.blogspot.com.br/2013/01/boa-tarde-meus-bensfeliz-ano-novo.html Acesso em: 21/01/2013; A metáfora (62) está disponível em:

http://www.catequisar.com.br/texto/colunas/jeronimo/12.htm Acesso em: 12/02/2014; A sentença metafórica (63) está disponível em: http://pensador.uol.com.br/frase/MTE1MTc3NA/ Acesso em: 12/02/2014; A sentença (64) está disponível em: http://br.answers.yahoo.com/question/index?qid=20131026001233AA1fCah Acesso em: 12/02/2014; A metáfora (65) está disponível em:

https://twitter.com/HeloisaRosa/status/252970452409016320 Acesso em: 12/02/2014; A sentença (66) está disponível em: http://www.tribunabm.com.br/o-amor-caminha-ao-lado-do-perdao/ Acesso em: 12/02/2014; A 
sentença (67) está disponível em: http://www.tribunabm.com.br/o-amor-caminha-ao-lado-do-perdao/ Acesso em: 12/02/2014; A sentença metafórica (68) está disponível em: http://aventar.eu/2009/12/27/no-rastro-dasexualidade-camimha-o-amorno-rastro-do-amor-caminha-a-sexualidade/ Acesso em: 12/02/2014; A sentença metafórica (69) está disponível em:

http://fanfiction.com.br/historia/285773/O_Amor_Caminha_Ao_Meu_Lado/capitulo/1 Acesso em: 13/02/2014; A sentença (70) está disponível em: http://blogdatacia.wordpress.com/2013/01/06/transicao-nem-sempre-apaixao-caminha-rumo-ao-amor/ Acesso em: 13/02/2014; A sentença metafórica (71) está disponível em: http://www.pinterest.com/josefinaspt/vermelho-paix\%C3\%A3o-passionate-red/ Acesso em: 13/02/2014; A metáfora (72) está disponível em: http://www.viveiros.com.br/site/index.php/artigos/futebol-para-onde-caminhaa-paixao/ Acesso em: 13/02/2014. A sentença (73) está disponível em: http://www.startribune.com/photostornado-damaging-winds-whip-through-minnesota/316814411/\#1 Acesso em: 07-09-2015; A sentença (74) está disponível em: http://news.xin.msn.com/en/storm-batters-europe-7 Acesso em: 19-05-2014; A metáfora (75) está disponível em: http://foundthings.com/post/73594785954 Acesso em: 19-05-2014; A sentença metafórica (76) está disponível em:

http://www.mlive.com/news/muskegon/index.ssf/2014/04/aftermath_of_muskegon_storm_ke.html Acesso em: 19-05-2014; A sentença (77) está disponível em: http://www.csmonitor.com/USA/2014/0214/Massive-storm-sparting-shot-Huge-pileup-on-Pennsylvania-Turnpike-video Acesso em: 19/05/2014; A metáfora (78) está disponível em: http://thinkprogress.org/climate/2013/07/30/2378791/tropical-storm-flossie-hits-hawaii/ Acesso em: 19/05/2014; A sentença metafórica (79) está disponível em:

http://english.peopledaily.com.cn/90001/90777/90852/6958229.html Acesso em: 19/05/2014; A sentença (80) está disponível em: http://english.peopledaily.com.cn/90001/90777/90852/6958229.html Acesso em: 19/05/2014; A metáfora (81) está disponível em:

http://earthobservatory.nasa.gov/NaturalHazards/view.php?id=14560 Acesso em: 19/05/2014. Sentença metafórica (82) está disponível em: http://www.startribune.com/photos-tornado-damaging-winds-whip-throughminnesota/316814411/\#1 Acesso em: 07/09/2015; A sentença (83) está disponível em:

http://www.nwitimes.com/news/local/lake/winds-whip-trees-as-brief-storm-batters-n region/article 6dd459a38cec-5155-a46d-8d5a26f993a4.html Acesso em: 10/04/2014; A metáfora (84) está disponível em: http://www.theguardian.com/uk/2012/jan/05/strong-winds-sweep-across-britain Acesso em: 14/04/2014; A sentença (85) está disponível em: http://www.clickondetroit.com/weather/high-wind-warning-in-effect-untilnoon/25464962 Acesso em: 14/04/2014; A metáfora (86) está disponível em:

http://www.accuweather.com/en/weather-news/record-cold-a-freeze-and-bitin/24852920 Acesso em: 14/04/2014; A metáfora (87) está disponível em: http://www.thelocal.se/20131205/storm-sven-sweeps-intosouthern-sweden Acesso em: 16/04/2014; A sentença metafórica (88) está disponível em:

http://www.ajc.com/news/news/local/heavy-rain-high-winds-sweep-across-metro- atlanta/ndXMW/ Acesso em: 16/04/2014; A metáfora (89) está disponível em: http://www.ajc.com/news/news/local/heavy-rain-high-windssweep-across-metro-atlanta/ ndXMW/ Acesso em: 16/04/2014; A sentença metafórica (90) está disponível em: http://www.telegraph.co.uk/topics/weather/10541264/Householders-braced-for- more-flooding-as-80mph-windssweep-in.html Acesso em: 16/04/2014; A metáfora (91) está disponível em:

http://www.birminghammail.co.uk/news/midlands-news/pictures-gale-force- winds-sweep-through-6703048 Acesso em: 16/04/2014; A sentença metafórica (92) está disponível em:

http://www.dallasnews.com/news/metro/20140315-rain-high-winds-sweep-dallas-fort-worth.ece Acesso em: 16/04/2014; A metáfora (93) está disponível em: http://www.kcci.com/news/central-iowa/more-gusting-windssweep-through-central-iowa/24001276 Acesso em: 16/04/2014; A sentença (94) está disponível em: http://www.asianewsnet.net/SE-Asia-shivers-as-cold-winds-sweep-through-56473.html Acesso em: 17/14/2014; A sentença (95) está disponível em: http://www.nbclosangeles.com/news/local/Wind-Gusts-Fire-Weather-RedFlag-Warning-SoCal-LA-Forecast-249718601.html Acesso em: 17/04/2014; A metáfora (96) está disponível em: http://tevel1.com:81/news/uk-26183403Acesso em: 17/04/2014; A sentença metafórica (97) está disponível em: http://abclocal.go.com/kabc/story?id=9360562 Acesso em: 17/04/2014; A sentença (98) está disponível em: http://trove.nla.gov.au/ndp/del/article/49727523 Acesso em: 17/04/2014; A sentença metafórica (99) está disponível em: http://www.hulldailymail.co.uk/Weather-update-Strong-winds-sweep-Hull-East/story20614507detail/story.html\#ixzz30MujeQhpAcessoem: 30/04/2014; A sentença (100) está disponível em: http://www.foxnews.com/us/2013/11/17/tornadoes-high-winds-sweep-through-midwest-causing-damagedelaying-bears-game/ Acesso em: 30/04/2014; A metáfora (101) está disponível em: http://www.huffingtonpost.co.uk/2013/12/05/uk-weather-flooding_n_4389001.html Acesso em: 30/04/2014; A sentença metafórica (102) está disponível em: http://www.vcstar.com/news/2013/dec/09/cold-and-windyweather-in-ventura-county-monday/ Acesso em: 30/04/2014; A sentença (103) está disponível em: http://metro.co.uk/2014/01/26/cats-lifted-in-the-air-by-mini-tornado-as-high-winds-sweep-through-surrey-andsussex-4277713/ Acesso em: 30/04/2014; A sentença (104) está disponível em: http://www.wmur.com/news/nhnews/thousands-lose-power-as-strong-winds-sweep-state/22325052\#ixzz30ro37k18 Acesso em: 05/05/2014; A 
metáfora (105) está disponível em: http://www.washingtonpost.com/pb/national/tornadoes-high-winds-sweepthroughmidwest/2013/11/17/d7d541c8-4fbe-11e3-a7f0-b790929232e1_gallery.html\#item0 Acesso em: 05/05/2014; A sentença metafórica (106) está disponível em: http://blogs.sfweekly.com/thesnitch/2013/11/high_winds_sweep_the_bay_area.php Acesso em: 05/05/2014; A sentença metafórica (107) está disponível em:

http://www.bournemouthecho.co.uk/news/10906916.New_Year_travel_disruption_expected_as_heavy_rain_and _strong_winds_sweep_across_Dorset/?ref=var_6 Acesso em: 05/05/2014; A metáfora (108) está disponível em: http://www.nzherald.co.nz/aucklander/news/image.cfm?c_id=1503378\&gal_cid=1503378\&gallery_id=140356\# 13817547 Acesso em: 05/05/2014; A sentença metafórica (109) está disponível em:

http://www.lehighvalleylive.com/sports/index.ssf/2012/11/cold_northwest_winds_sweepin.html Acesso em: 05/05/2014; A sentença metafórica (110) Disponível em: https://www.facebook.com/quickscooterridersonly Acesso em: 07/09/2015; A metáfora (111) está disponível em: http://www.dailymail.co.uk/news/article2554557/Gales-80mph-heavy-rainfall-create-flooding-misery-Britain-fresh-series-storms-sweepin.html\#ixzz30rvOMBZ6 Acesso em: 05/05/2014; A sentença metafórica (112) está disponível em: http://www.dailymail.co.uk/news/article-2554557/Gales-80mph-heavy-rainfall-create-flooding-misery-Britainfresh-series-storms-sweep-in.html\#ixzz30rvOMBZ6 Acesso em: 05/05/2014; A metáfora (113) está disponível em: http://www.theguardian.com/world/2014/apr/28/tornado-storm-us-dead-iowa-mississippi-arkansas Acesso em: 21/05/2014; A sentença metafórica (114) está disponível em:

https://www.google.com/search?q=storm+sweep\&oq=storm+sweep\&aqs=chrome..69i57j015.9448j0j7\&sourceid =chrome\&es_sm=93\&ie=UTF-8 Acesso em: 21/05/2014; A sentença (115) está disponível em:

http://www.usatoday.com/picture-gallery/weather/2014/05/01/storms-sweep-through-central-and-southernstates/8389613/ Acesso em: 21/05/2014; A sentença (116) está disponível em:

http://www.cbsnews.com/videos/severe-storms-sweep-midwest-south/ Acesso em: 21/05/2014; A metáfora (117) está disponível em: http://www.foxnews.com/us/2014/05/08/storms-sweep-across-great-plains-bringingstrong-winds-tornadoes-and-deluge/ Acesso em: 21/05/2014; A sentença (118) está disponível em: http://dictionary.cambridge.org/dictionary/english/whip Acesso em: 07/09/2015; A sentença metafórica (119) está disponível em: http://pittsburgh.cbslocal.com/2014/05/13/powerful-storms-sweep-through/ Acesso em: 21/05/2014. A metáfora (120) está disponível em: http://www.amazon.com/The-Soul-Speaks-ZaraMarselian/dp/1453766707 Acesso em: 14/06/2014; A sentença (121) está disponível em:

http://www.pinterest.com/soulspeak8/let-your-soul-speak/ Acesso em: 14/06/2014; A metáfora (122) está disponível em: http://www.vanguardngr.com/2012/10/the-soul-speaks/ Acesso em: 14/06/2014; A sentença metafórica (123) está disponível em: http://buildingsoul.ca/2013/10/22/the-soul-speaks-in-the-poetic-languageof-the-senses/ Acesso em: 14/06/2014; A sentença (124) está disponível em:

http://anunsilencedvoice.com/2012/03/12/when-the-soul-speaks/ Acesso em: 14/06/2014; A metáfora (125) está disponível em: http://aphotographicsage.blogspot.com.br/2013/11/the-soul-speaks-through-images-carljung.html Acesso em: 14/06/2014; A sentença (126) está disponível em:

http://www.signalsfromthesoul.com/category/soul-speaks-itself/ Acesso em: 14/06/2014; A sentença metafórica (127) está disponível em: http://southernrootsandnorthernblossoms.com/2014/04/27/when-the-soul-speaks/ Acesso em: 14/06/2014; A metáfora (128) está disponível em: http://lissarankin.com/can-you-hear-the-voiceofyour-soul Acesso em: 14/06/2014; A sentença (129) está disponível em: http://www.phyllismathis.com/schoolof-liferecordings/ Acesso em: 14/06/2014.

\section{Thabyson Sousa Dias}

Graduando do curso de Letras, do $8^{\circ}$ período, da Universidade Federal do Tocantins (UFT). E-mail: thabyson.sd@uft.edu.br

Endereço: Universidade Federal do Tocantins (UFT) |Câmpus de Araguaína - Avenida Paraguai s/nº ${ }^{\circ}$ Setor Cimba, Araguaína/TO | 77824-838

\section{Dieysa Kanyela Fossile}

Doutora em Linguística pela Universidade Federal de Santa Catarina (UFSC). Pesquisadora e professora adjunta II vinculada ao curso de Letras e ao Programa de Pós-Graduação em Letras: Ensino de Língua e Literatura, da Universidade Federal do Tocantins (UFT), Campus de Araguaína. Coordenadora do Grupo de Estudos Metafóricos (GEM/UFT) e dos projetos de pesquisa: (a) "Regularidade interpretativa: o significado aspectual na interpretação das sentenças metafóricas verbais do PB e do Inglês" e (b) "Livros didáticos de Língua Portuguesa: com o olhar focado no ensino de semântica". 
E-mail: dieysafossile@bol.com.br; dieysa@mail.uft.edu.br.

Endereço: Universidade Federal do Tocantins (UFT) | Câmpus de Araguaína - Avenida Paraguai s/nº ${ }^{\circ}$ Setor Cimba, Araguaína/TO | 77824-838 